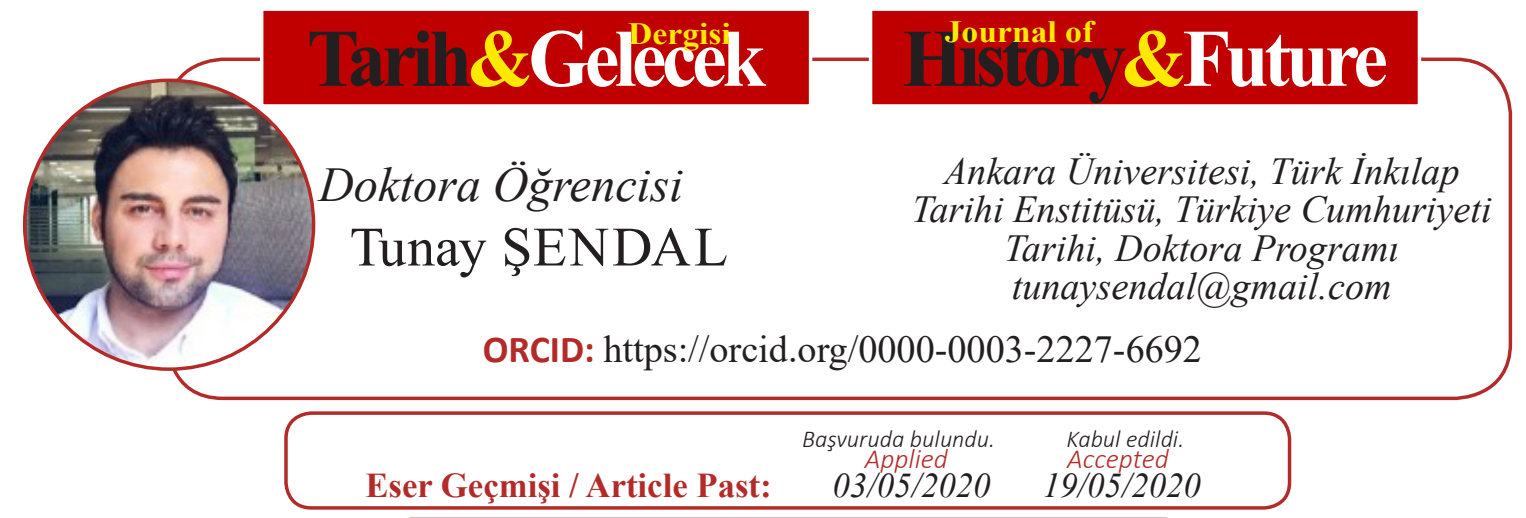

DOI: http://dx.doi.org/10.21551/jhf.731350

Research Paper

Orjinal Makale / Orginal Paper

\title{
Cumhuriyet Halk Partisinde Ortanın Solu İle Başlayan Siyasal Metamorfoza Karşı İç Ve Dış Muhalefet
}

\author{
Internal and External Opposition to the Political Metamorphosis \\ that Began with the Left of the Center in the Republican People's \\ $\ddot{O} z$ \\ Party
}

Türk siyasal hayatına damgasını vuran en önemli gelişmelerden birisi; ülkenin kurucu ideolojisinin temsilcisi olan Cumhuriyet Halk Partisi'nde 1960'll ylllarda yaşanan siyasal metamorfoz sürecidir. 1953 yll itibariyle bir muhalefet partisi olarak özgürlükçü söylemlere yönelen CHP, 1965 yılında yeni bir ideolojik kimlik ile "Ortanın Solu" söylemini benimsemiştir. CHP'nin bu zamana kadarki gerçekleştirmeye çalıştı̆̆ demokratikgelişim ve siyasi konjonktürün etkisiyle ortaya çıkan bu siyasi metamorfoz süreci; 1965 seçimlerinden önce tartışılmaya başlanmış ve parti içi ve parti dışı birçok tartışmayı da beraberinde getirmiştir. Açılımın tartışılmasıyla birlikte başlayan siyasal metamorfoz; Ortanın Solu ekibinin Merkez Yönetim Kurulu'na hâkim olması ile beraber ivme kazanmıştır. Zaman içerisinde Ortanın Solu'na ilişkin tartışmalar parti içi iktidar mücadelesine dönüşürken bu süreç esnasında parti içi ve parti dışı muhalefet, çeşitli gruplar ile birlikte Ortanın Solu hareketine karşı etkinliğini arttırmıştır. Parti içindeki; 'Sekizler', ' 'Ortanın Göbekçileri',, 'Ü̧̈üncü Dünyacılar', 'Sosyalist-Marksist Sol'” gibi gruplar ile hizipleşme mücadelesi veren 'Ortanın Solu', parti dışından sol fraksiyondaki TiP ve Yön'ün, sağ fraksiyondan ise özellikle Adalet Partisi'nin eleştirilerine maruz kalmıştır.

Anahtar Kelimeler: Cumhuriyet Halk Partisi, Ortanın Solu, İsmet İnönü, Bülent Ecevit, Parti İçi ve Parti Dışı Muhalefet

\section{Abstract}

One of the most significant developments that marked the Turkish political life in the 1960s was the process of political metamorphosis and in the Republican People's

ATIF: ŞENDAL Tunay, "Cumhuriyet Halk Partisinde Ortanın Solu İle Başlayan Siyasal Metamorfoza Karşı İç Ve Diş Muhalefet”, Tarih ve Gelecek Dergisi, 6/2 (Haziran 2020), s. (281-302)

CITE: ŞENDAL Tunay, "Internal and External Opposition to the Political Metamorphosis that Began with the Left of the Center in the Republican People's Party", Journal of History and Future, 6/2 (June 2020), pp. (281302) 
Party, the representative of the constitutive ideology of the country. CHP, which ran to libertarian speech as an opposition party beginning from 1953, adopted "Middle Left" as a new ideological definition in 1965. This political metamorphosis process, which emerged with the effect of the democratic development and political conjuncture that the CHP has so far tried to achieve; It started to be discussed before the 1965 elections and brought many discussions both inside and outside the party. Political metamorphosis, which started with the discussion of discourse; It gained momentum with the Mid-Left team, which dominated the Central Board of Directors. While the discussions on the Left of the Center turned into a power struggle within the party, the internal and external opposition increased their effectiveness against the Middle Left movement with various groups. The Left of the Center, struggled with groups such as the Eights, the Hubs of the Middle, the Third Worldists, the Socialist-Marxist Left. And it, on the other hand, outside the party, the left wing was criticized by the TIP and Yön and the right wing Justice Party.

Keywords: Republican People's Party, Left of the center, İsmet İnönü, Bülent Ecevit, In-party and non-party opposition

\section{Giriş}

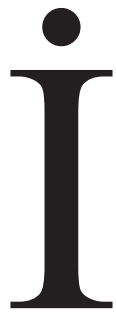

kinci Dünya Savaşı'nın ardından dünyada yeni oluşan siyasi konjonktür, içeride ve dışarıda vukuu bulan yeni koşullar ile birlikte, ülkenin tek partisi konumunda bulunan Cumhuriyet Halk Partisi(CHP)'ni mecburi bir değişime itmiştir. Bu yeni siyasi ortama ayak uydurabilmek adına birtakım değişikliklere kap1 aralayan CHP, 1945'ten sonra yeni yasal düzenlemelere girişmiştir. 1946 yılında çok partili siyasal hayatın başlaması ve Demokrat Parti(DP)'nin kurulması, CHP'de yenilenerek yürütülen politikaları revize etme, bir başka ifade ile partiye yeni bir kimlik kazandırma gerçeğini gün yüzüne çıkarmıştır. Bu doğrultuda 1947 yılında yapılan Kurultay'da esmeye başlayan değişim rüzgârları, dünyada ve ülkede 1945 sonrası ortaya çıkan yeni siyasi atmosferin bir yansıması olmuşsa da esasında, partideki değişim dinamizminin temelleri 1946 yılında düzenlenen CHP'nin İkinci Olağanüstü Kurultayı'na dayanmaktadır. ${ }^{1}$

1947 Kurultayı, gerek Türk siyaseti gerekse CHP açısından önemli bir yer tutar. Keza bütünleşmiş bir parti-devlet kimliğine sahip olan CHP'nin bu zaruriyet teşkil eden değişimi, yalnızca partiyi alâkadar eden bir durum değil aynı zamanda ülkedeki mevcut siyasal yapının da değiştirilmesi anlamını taşımaktadır. CHP'nin 1947 Kurultayı'nda almış olduğu kararlar ülkedeki demokrasi anlayışının işlev bir durumda yürütülmesi veya kurumsallaşabilmesi adına oldukça önemlidir. 1947 Kurultayı hem parti ile ilgili, hem de Türkiye'deki demokratik sistemin gelişimiyle alâkalı alınan kararlar babında önem arz ederken CHP'nin kendi içinde gerçekleştirmeye çalıştığı bir değişim hareketiyle de ön plana çıkmıştır. Uzun yıllar devrimlerin ve toplumun tamamının temsilcisi olma iddiasını taşıyan

1 Hakan Uzun, “İktidarını Sürdürmek İsteyen Bir Partinin Kimlik Arayışı: Cumhuriyet Halk Partisi’nin 1947 Olağan Kurultayı", Dokuz Eylül Üni. Atatürk İlkeleri ve Inkllâp Tarihi Enstitüsü Çăgdaş Türkiye Tarihi Araştırmaları Dergisi, C. XII, 25, Y11 2012/Güz, s.133. 
ve devletle bütünleşmiş bir özelliği kendi içerisinde eriten kurucu-iktidar, Cumhuriyet tarihi ile özdeşleşerek ' 'gerçek" bir siyasal parti olma vasfını kaybetmiştir. Dolayısıyla 1947 Kurultayı, CHP için çok partili siyasal yaşam içerisinde, iktidarını devam ettirebilmek ve gerçek bir siyasi parti kimliğine sahip olabilmek adına, kendini revize etmeye çalıştığı bir atılımdır. Lakin bu gaye çerçevesinde alınan kararlar ve bu doğrultuda vücut bulan icralar, bir açıdan mecburi bir realiteyi gözler önüne sererken CHP'yi diğer partilerden ayıran farklılıklarını yok ederek öteki siyasal partilerle benzetmesi açısından da bir hataya sevk ediyordu. Bundan dolayı 1947 Kurultayı'nın kararları, esasında bir yenilik hareketinden daha ziyade diğer partilere benzeme çabası olarak kalmıştır. ${ }^{2}$ Zira bu çerçevede ş̧ekillenmeye çalışan bir yenilenme girişiminin yeni siyasal iklim içerisinde başarılı olabilme ihtimali mümkün olmamıştır. Ancak CHP'nin yenilik girişimlerindeki başarısızlığının temelinde değişimi; diğer partilere benzeme ile özdeşleştirmesinin yanı sıra aynı zamanda uzun ve kesintisiz iktidar yıllarından kaynaklı toplumda hissedilen sıkılma ve yenilik arzusunun da var olduğu göz ardı edilmemelidir. İkinci Dünya Savaşı'nın ülkeye yansıttığı sıkıntıların ardından, çok partili hayatın başlamasıyla birlikte kendine özgü bir yenilenme girişimi gerçekleştiremeyen CHP'nin, ideolojik kimlik arayışı uzun yıllar sürerken CHP bu arayışın esaslı icraatını "Ortanın Solu" akımı ile birlikte hayata kazandırmıştır. Nihayetinde kamuoyu karşısında yeni bir söylem ve Ecevit gibi yeni bir liderle boy gösteren CHP, 1970'li yıllarda halk nezdinde umudun yeni adı olabilmiş ve bu siyasal metamorfoz ${ }^{3}$ halk tabanında ciddi bir destek yakalayabilmiștir. Zira mezkûr durumun tezahüründe, sol fraksiyon popülaritesinin o y1llarda dünya ve Türkiye genelinde estirdiği rüzgar da etkili olurken partinin mevcut siyasi konjonktürü doğru değerlendirebildiği de ayrı bir gerçekliktir. ${ }^{4}$

Ortanın Solu Kavramı, Türk siyasetinde 1960 yılının Ağustos ayı sonlarında İsmet İnönü ile dönemin CHP Genel Sekreteri İsmail Rüştü Aksal'ın, partinin izleyeceği yolu saptamak için Heybeliada'da, bir araya geldikleri görüşmelerde ilk kez gündeme gelmiş ve ilk defa Metin Toker'in Akis Dergisi'nin 31 Ağustos tarihli sayısında Türk basınında yer almıştır. ${ }^{5}$ Ancak içi doldurulamayan söylemin parti içerisinde dile getirilmesi beş yıllık bir zaman dilimini kapsamıştır. 1965 seçimleri öncesinde, bir parti ilçe teşkilatı istişaresi sırasında Ortanın Solu kavramı İsmet İnönü tarafından ilk kez bir parti organında dile getirilmiş ve Genel Başkan: “CHP'nin partiler yelpazesindeki yerinin Ortanın solunda olduğunu" söylemiştir. ${ }^{6}$ Mevcut tablo ülkede yerleşmeye başlayan demokrasinin tabii bir neticesi olarak CHP'nin işlevselliğini yitirmiş 'eski' kimliğinden siyrılıp, farklı bir söylemle toplum önüne çıkışının bir ürünü ve aynı zamanda siyasi yelpazedeki yerini belirlemesidir. Ancak Ortanın Solu akımının ortaya çıkışında; 1960 Askeri müdahalesi, yeni anayasa, Türkiye İşçi Partisi(TIP)'yle benimsenen sol fraksiyonun yükselişine değin giden bir entelektüel geçmişin etkisi de mevcuttur. ${ }^{7}$ Parti-devlet bütünleşmesi sonucu bir

\footnotetext{
2 Uzun, s.133.

3 Biyolojide "Başkalaşım" anlamına gelen terim, bu çalışmada siyasi değişim, dönüşüm manasında kullanılmıştır.

$4 \quad$ Uzun. s.133.

5 Metin Toker, "Yurtta Olup Bitenler", Akis, 31 Ağustos, 1960, s. 26.

6 Gülsüm Tütüncü Esmer, Türk Siyasal Yaşamında Ortanın Solu Politikası, Dokuz Eylül Üniversitesi Sosyal Bilimler Enstitüsü Tarih Ana Bilim Dalı Yayınlanmamış Yüksek Lisans Tezi, 2006, s. 19.

7 Yunus Emre, CHP, Sosyal Demokrasi ve Sol, İletişim Yayınları, İstanbul, 2013, s. 47-50.
} 
kamu kurumu görünümündeki CHP'yi gerçek bir siyasi parti hâline getirmeyi hedefleyen bu siyasal metamorfoz, aynı zamanda CHP'yi demokratlaştırırken son tahlilde ise CHP'ye sosyal demokrat bir kimlik kazandırmıştır.

Ortanın Solu kavramı, tam bir ideoloji kimliği yansıtmaktan daha ziyade politik doktrin olarak gelişen bir ilkeler bütünüdür. Politik doktrin, toplumu idare etme ya da yönetme yetkisinin kazanılması ve pratize edilmesiyle ilgili hususta savunulan, öğretilen ve icra edilen politika, görüş veyahut prensip anlamını taşımaktadır. Politik doktrin terimi çoğu kez siyasi ideoloji kavramı ile karıştırılmaktadır. Lakin doktrin, ideolojinin devinimi açısından eksiklikler barındırır ve belirli bir konuyla alakalı ne olması gerektiğinin tutarlı bir ifadesidir. Bu açıdan da salt manada teorik bir söylemdir. Meta-teorik manada felsefik öğretilerle ilgilenen Politik doktrin, başlı başına siyasi bir kimliğin oluşmasından ve ideolojinin prototipinden evvel, belirli bir mantalitesi olan bir değerler setine dayanır. ${ }^{8}$ Bu manada Ortanın Solu kavramı, CHP'de sosyal demokrasinin kapılarını aralayan hatta demokratik solun da tohumlarını filizlendiren bir politik doktrin vasfina sahiptir.

Buçalışma; 1960'ly y1llara damga vuran ve CHP'de yaşanan mezkûr siyasal metamorfoz sürecinin dinamiğini oluşturan Ortanın Solu akımının ortaya çıkışı ile birlikte devinimini kaybedene kadar ki geçen süreci bir bütün olarak ele almaktan daha ziyade Ortanın Solu'na karşı parti içinde çeşitli tartışmalarla cereyan eden muhalif fikir ve hizipleşme ortamının yanı sıra parti dışı diğer cenahlardan yansıyan karşıt görüşleri farklı gruplar ve başlıklar altında inceleyerek mercek altına almayı amaçlamıştır.

\section{Ortanın Soluna Karşı Parti İçi Muhalefet}

1958 yılında yapılması planlanan genel seçimlerin erken seçim kararı ile 1957 yılına çekilmesi, CHP'yi hızlandırmıştı. 1954 seçimlerinde geleneksel yapısını koruyarak revizyon yapmayan ve 1950 seçimindeki tablonun 1954 seçimlerinde değişeceğini düşünen CHP, bu defa daha kötü bir hezimetle karşı karşıya kalınca 1957 seçimleri adına daha özverili davranmayı akıl etti. Zira tek parti dönemi politikalarının devam ettirilmesi de siyasi konjonktür gereği anakronik bir tablo oluşturmaktaydı. Değişim rüzgarlarının temelini CHP'nin 13. Kurultay'ında okunan "Hürriyet Andı" oluştururken andın içeriğinde şu ifadeler yer almaktaydı:

“Ülkemizin bugünkü siyasal durumu ve bu durumun partimizin 13. Kurultayı'na yüklediği tarihi görev birleşmiş muhalefet cephesinin bir üyesi olan biz CHP'liler, Türk milletini layık olduğu ileri demokratik rejime ve vatandaşlar arasında eşit muameleyi ilke edinen hukuk devletine kavuşturmaya ve millet iradesinin tecellisine engel olmak isteyenlerin karşısında hiçbir şeyden yılmadan, kanuna uyup ulu Tanrı'ya sığınarak mücadele etmeye and içtiğimizi işbu hürriyet andıyla kabul ve ilan ederiz." ${ }^{9}$

Bu defa daha ciddi ve daha özverili çalışan CHP, topluma daha fazla kulak veren bir imaj çiziyordu. Düzenlenen mitinglerde Şemsettin Günaltay gibi isimler İşçiye grev hakk1 tanıyacaklarını bildiriyordu. ${ }^{10} 1957$ Seçim Beyannamesi ile köylü, işçi ve esnaf sorunlarına

8 Bernard Crick, Demokrasi, Çev: Ümit Hüsrev Yolsal, Dost Kitabevi, Ankara, 2012.

9 Hikmet Bila, CHP 1919-2009, Doğan Kitap, İstanbul, 2008, s.148.

10 Bila, s.149. 
daha fazla eğilen, memlekette tüm demokratik kurumların kurulmasının ardından seçimlerin tüm partilere eşit haklar sağlanarak yenileneceğini dile getiren bir söylem geliştirildi. CHP iktidara geldiğinde nispi temsil sistemini sağlayacak, kalkınmayı plan ve programa göre tahsis edecek, Yüksek Hâkimler Şurası, Çift Meclis ve Anayasa Mahkemesi gibi kuracağı müesseselerle seçimleri yenileterek demokratik bir düzen getirecekti. ${ }^{11} \mathrm{Bu}$ yeni siyaset tarzı, 1957 seçimlerinde CHP'ye iktidar kapılarını aralamasa bile halk nazarında karşılık buldu. DP'nin oy oranı düşüş yaşamış, CHP ise oy oranını yükseltmişti. DP'den ispat hakkı tartışmaları nedeniyle ayrılarak kurulan Hürriyet Partisi(HP) ${ }^{12}$ ise seçimlerde umduğunu bulamayan bir diğer siyasi parti olmuştu. ${ }^{13} 1957$ seçimlerinin hezimeti HP'de kopuşlara neden olmuş, partinin CHP'ye katılması konuşulmaya başlamıştı. ${ }^{14}$

HP'nin 1958 yılında CHP'ye katılmasıyla birlikte CHP içinde liberal görüş hakim olmaya başlarken parti programı yeniden değiştirildi ve değişen program mevcut anayasada bir revizyon öngörüyordu. ${ }^{15}$ Bu revizyonist program nispi temsil, ikili meclis, sosyal adalet, hukukun üstünlügü gibi konuları kapsamaktaydı. ${ }^{16} 1957$ yılında yapılan genel seçimler ile oy oranını arttıran CHP, HP'nin de partiye dahil olmasiyla birlikte daha aktif bir tempo kazandı. TBMM'de Milli Korunma Kanunu'nun kaldırılması ve grev hakkı gibi konuları kapsayan kanun taslakları öneren CHP'nin tutumundaki yönelim, 1959 yılında gerçekleşen 14. Kurultay ile son şeklini almış oldu. ${ }^{17} \mathrm{Bu}$ açıdan bakıldığında Ortanın Solu akımının ilk fikirsel hareketleri, CHP'nin 14. Kurultay'da duyurulan "illk Hedefler Beyannamesi” nde karşımıza çıkmaktadır. ${ }^{18}$

Liberal çizgiye yakın olarak bilinen HP'nin CHP'ye katılmasının ardından düzenlenen ilk kongre olan 14.Kurultay, HP ve CHP arasındaki uzlaşı neticesinde karar kılınan konuların müzakeresi adına düzenlenmiştir. İlk Hedefler Beyannamesi'nin raportörü HP'den Turan Güneş olmuştur. Cemal Fedayi’ye göre Turan Güneş; Ortanın Solu akımının entelektüel lideridir. ${ }^{19} \mathrm{Bu}$ bağlamda Ortanın Solu akımı, liberal bir damardan beslenerek sosyal demokrasi ve siyasal liberalizmi de içermiştir. Partide kurultaylar sonrasında yeni parti programlarının genel hatlarını oluşturan bir bildirinin ilan edilmesi gelenekselleşmiştir.

11 Metin Toker, DP Yokuş Aşăğ - Demokrasimizin İsmet Paşa’lı Y1lları 1944-1973, Bilgi Yayınevi, Ankara, 1991, s.262.

12 Basına ispat hakk1 verilmesini isteyen, Demokrat Parti'li19 milletvekilinin talepleri Demokrat Parti Grubu tarafından reddedilince 19 milletvekilinden 10'u partiden ayrılmış, 9'u ise partiden ihraç edilmiştir. Bunun üzerine DP'den ayrılan muhalif milletvekilleri 19 Aralık 1955 tarihinde Hürriyet Partisi'ni kurmuştur. Türk siyasetinde istediğini elde edemeyen Hürriyet Partisi, 24 Kasım 1958 tarihinde kendini feshetmiş ve Cumhuriyet Halk Partisi'ne katılmıştır. Bknz. Diren Çakmak, " Türk Siyasal Yaşamında Bir Muhalefet Partisi Örneği: Hürriyet Partisi (1955-1958)", Akademik Bakış, Cilt 2, Sayı 3 Kış 2008. s. 153-186.

13 Emre, s. 80.

14 Akın Simav, Turan Güneş’in Siyasal Kavgaları, Agora Kitaplığı, İstanbul. 2009, s.40-48.

15 Emre, s. 80.

16 Ayşe Güneş Ayata, Cumhuriyet Halk Partisi (Örgüt ve İdeoloji), Gündoğan Yayınları, İstanbul, 1992 , s.80.

17 Bila, s. 151.

18 Fatih Tuğluoğlu,’CHP’nin 14. Kurultayı ve İlk Hedefler Beyannamesi’, Atatürk Yolu Dergisi, 2017, C.15 Say1:60.

19 Cemal Fedayi, Turan Güneş: Siyasal Yaşamı ve Siyasal Düşüncesi, Ankara, Hacettepe Üniversitesi Yayınlanmamış Doktora Tezi, 2003, s.262-279. 
Bundan mütevellit Ortanın Solu akımının zuhur edişinde 13. Kurultay'dan başlayan ve 1965 öncesi düzenlenen kurultaylarda duyurulan her bildirinin önemli bir payı mevcuttur. 15. Kurultay'da ilan edilen Temel Hedefler Beyannamesi ve 17. Kurultay'da yayınlanan İleri Türkiye Ülküsü 1965 öncesinde Ortanın Solu akımının gelişimine katkısı olan iki önemli bildirgedir. 15. Kurultay'da yayınlanan Temel Hedefler Beyannamesi ekonomik bir içeriğe sahipken 17. Kurultay'da yayınlanan İleri Türkiye Ülküsü daha çok sosyal içerikli konuları kapsamaktadır. Bu bağlamda Ortanın Solu akımının alt yapısının oluşumunda siyasi açıdan İlk Hedefler Beyannamesi, ekonomik açıdan Temel Hedefler Beyannamesi sosyal yönden ise İleri Türkiye Ülküsü bildirileri temel oluşturmuştur yorumu yapılabilir. ${ }^{20}$

CHP'de esen bu rüzgârların değişim odaklı bir tartışma haline gelmesini, ' Ortanın Solu" ifadesinin keşfinde rol oynayan İbrahim Öktem'in parti meclisine verdiği takrir başlatmıştır. 1961 yılındaki bu mezkur parti meclisi istişaresi, aynı zamanda parti için mühim bir kırılma anının ilk hamlesini oluştururken ayrıca sonraki dönemlerde daha somut bir kimlik kazanacak olan akımın, parti teşkilatı içerisindeki ilk faal çıkışını da temsil etmektedir. Parti meclisinde ilk olarak sözü Turan Güneş almış ve an itibariyle partiye köylü ve işçi gibi yoksul grupların çıkarlarını hedef edinen ve bu kesimlerin refahını yükseltmeyi amaçlayan farklı bir yön kazandırılması gerektiğini, bilhassa nisbi temsile geçilmesinin ardından her zümreden birinin tek çatı altında toplanamayacağını belirtmiştir. Güneş’ten sonra, Bülent Ecevit onu destekleyen mahiyette bir konuşma yapmış, ardından İbrahim Öktem, tartışmanın neticeye vararak partinin seyredeceği yönün belirlenmesi amacıyla bir önerge vermiştir. ${ }^{21} \mathrm{Bu}$ tarihi çıkışın dışında Yön de 4 Nisan 1962 tarihinde yayınlanan "C.H.P.: Yön Aranıyor" başlıklı haber, parti içinde esmekte olan değişim rüzgarlarının şiddetini arttırmıştır. ${ }^{22}$ Görüldüğü gibi 1960 yılında ilk kez İsmet İnönü tarafından dillendirilen ve 1965 yılında tanımlanmaya çalışılan Ortanın Solu akımı, bu süreçlerden geçerek ortaya çıkmış ve tartışmaları da beraberinde getirmiştir.

Değişim rüzgârlarının sesi parti içerisinde tepkilere hatta gruplaşmalara bile neden olurken Ortanın Solu kavramına karşı oluşan tepkilerin ilki milliyetçi söylemleriyle tanınan Tahsin Banguoğlu ve sağ gruptan gelmiştir. Tahsin Banguoğlu, Genel Başkan İsmet İnönü için kaleme aldığ 1 bir mektupta; partide sosyalizme kayan bir tutum benimsediğini, bu durumun toplumsal sınıflaşmaya neden olacağı gibi devlet kapitalizmi ve teknokrasinin de önünü açacağını ifade etmiştir. ${ }^{23}$ Banguoğlu, İnönü’yü eleştirirken: “Atatürk doğuştan ülkücü, daha doğrusu 'ülkücü gerçekçi' bir önderdi. Halefi ise belki yine doğuştan 'maddeci-hayalci' bir şahsiyetti. Şöhretine ve büyük nüfuzuna dayandığı Atatürk'ün eserini şekilde korumaya çalıştı. Fakat onun ayrı bir dünya görüşüne, tarihi materyalizmine doğru gitmesi adeta mukadderdi. Nitekim öyle oldu." ${ }^{24}$ gibi ifadeler kullanmış ve bu sert eleştiriler Banguoğlu'nun partiden ihraç edilmesine sebep olmuştur. Banguoğlu'nun ihraç edilmesinden sonra liderlik yaptığı gruptaki R. Kunter, T. Sökmen, F. Güleç, F. Rıfkı Atay, İstiyordum”, Tarih ve Toplum, C. 24, Say1 141, Eylül 1995, s. 61-64.

21 “C.H.P.: Yön Aranıyor”, Yön, 4 Nisan 1962, Sayı 16, s.6.

22 Yön, 4 Nisan 1962, Sayı 16, s.6.

23 Nermin Abadan, “1966 Kısmi Senato Seçimlerinin Tahlili”, Forum, Say1: 294, 1966, s. 160.

24 Tahsin Banguoğlu, “Atatürk’ün Milliyetçiliği”, Ortam, Sayı:11, Ekim 1965. 
F. Şerafettin, Ş.R. Hatipoğlu, N. Özdemir, S. Çumralı, A. A. Bolak, H. D. Erginsoy, Oğuz Bekata gibi isimler ise bir süre daha Ortanın Soluna karşı parti içinde mücadeleye devam etmiştir. Seçimler esnasında Ortanın Soluna karşı ikinci muhalif hareket, CHP eski Genel Sekreteri Kasım Gülek tarafından gelmiş, parti umdelerinin yalnızca kurultayda alınan karar doğrultusunda değiştirilebileceğini bildiren Gülek, Ortanın Soluna açıkça karşı çıkmıştır. ${ }^{25}$

1965 Seçimlerinin ardından CHP içindeki tartışmalarla birlikte gruplaşma dörde ayrılmıştır: Birinci grup, İnönü'ye yakın olan ve Ortanın Solu akımını destekleyen ' 'Forum Grubu" dur. Bülent Ecevit, Turan Güneş, İbrahim Öktem, Orhan Birgit gibi isimlerin yer aldığı ekip sonrasında 'Ortanın Solu Ekibi' adıyla anılacak ve akımın kemik kadrosunu oluşturacaktır. İkinci grup; Mustafa Kemal Paloğlu, Selahattin Hakkı Esatoğlu, Şükrü Koç, Mustafa Ok, Murat Öner, Seyfi Sadi Pencap, Muammer Erten gibi isimlerden oluşan ve birinci gruba yakın olan 'Sol Grup' dur. Üçüncü grubu Cemal Reşit Eyüboğlu'nun önderliğindeki ' 'Marksist Ekip' oluştururken Turhan Feyzioğlu, İsmail Rüştü Aksal, Nüvit Yetkin, Ferit Melen gibi isimlerin başını çektiği dördüncü grup ise asıl muhalefeti oluşturan kanattır. ${ }^{26}$

Parti içi grupların mücadelesi ilk olarak İstanbul ve Ankara il kongrelerinde kendini göstermiştir. İstanbul il kongresinde Ortanın Solu kavramı, Turhan Feyzioğlu, İsmail Rüştü Aksal, Coşkun Kırca, Ferit Melen gibi isimlerce sert bir şekilde eleştirilmiş, seçim yenilgisi Ortanın Soluna bağlanmış ve Ortanın Solu'nun partiye zararı olacağı savunulmuştur. Tartışmalarla geçen İstanbul il kongresindeki bu eleştiriler, örgüt üzerinde de etkili olmuştur. ${ }^{27}$ Ortanın Solu ekibince, seçimlerde alınan mağlubiyetin mesuliyeti başkalarına yüklenmemeli ve özeleştiriyle hareket edilmelidir. Zira ancak bu şekilde CHP ve Türk demokrasisi refaha erebilir. ${ }^{28}$ Tartışmalar devam ederken Kemal Satı ${ }^{29}$, yeni akımın tanımı adına Nihat Erim ve Turhan Feyzioğlu gibi isimlerden oluşan bir komisyon oluşturmuştur. Ortanın Solu akımının 1966 yılındaki kısmi senato yenileme seçimlerinde, direkt yeni bir siyasi söylem olarak kullanılmaması ve seçim sonuçlarının CHP için 1965 seçimlerinden farklı olmaması Ortanın Solu Ekibi adına siyasi bir koz haline gelmiş ve yenilgi sonrasında başka tartışmalarda gün yüzüne çıkmıştır. Bu tartışmaların başında CHP'nin Ortanın Solu'nda değil "sağında" olması gerektiğini savunan Turan Feyzioğlu'nun muhalefeti de dikkat çekmektedir. ${ }^{30}$ Daha sonra Ortanın Soluna karşı muhalefetin başrollerinden biri

25 Esmer, s. 41. Celal Bozkurt, Siyasi Tarihimizde CHP Dünü, Bugünü ve İdeolojisi, Ankara,1967, s. 114.

26 Esmer, s. 54.

27 “CHP’nin Dertleri: Orta mı, Solu mu?”, Yarın, Sayı 180, 28 Eylül 1966.

28 Muammer Aksoy, “Demokrasi’nin Akıbeti-CHP ve Ortanın Solu”, Forum, Sayı 30, 15 Ekim 1966.

29 Kemal Satır; 1961'de Elazığ'dan milletvekili seçildi ve 1962 yılında CHP Genel Sekreteri oldu. Üçüncü İnönü Koalisyon Hükümeti kabinesinde Devlet Bakanı ve Başbakan Yardımcısı olarak görev aldı. 1965 yılında yapılan CHP Genel Kurulunda genel sekreterliği Bülent Ecevit'e devretti. Aynı dönemde yapılan seçimlerde Elazı̆̆'dan, 1969 yılında yapılan seçimlerde ise Adana'dan milletvekili seçildi. İsmet İnönü’nün CHP genel başkanlığından ayrılmasına yol açan beşinci olağanüstü kurultaydan sonra CHP'den ayrıldı. CHP'den ayrıldıktan sonra Cumhuriyetçi Parti (CP)'nin kurucuları arasında bulunarak genel başkan oldu. CP'nin Güven Partisi(GP) ile birleşmesi sonucunda Cumhuriyetçi Güven Partisi (CGP) adını alan partide ise genel başkan yardımcılığı görevine getirildi. 1971 Muhtırası'ndan sonra kurulan Ferit Melen Hükümeti'nde Devlet Bakanlığı ve Başbakan Yardımcılığ1 (1972-74) görevlerini ifa eden Kemal Satır, 1973'te seçimlerini kaybettikten sonra aktif siyaseti bıraktı. Bknz. Milliyet Büyük Larousse Sözlük ve Ansiklopedisi, 20. cilt, 1986.

Esmer, s. 43. 
olacak olan ancak partinin ağır toplarının muhalefete başladığı bu dönemde, sessiz kalmayı tercih eden Kemal Satır ise İnönü önderliğinde başlatılan akımı, anayasal bir yaklaşım olarak gördüğünden vahdaniyet anlayışıyla destek olduğunu açıklamıştır. Lakin bir zaman sonra partide "Yeni Tarihi Akım" olarak anılmaya başlayan akıma karşıt durduğunu ifade etmiştir. ${ }^{31}$ Ortanın Soluna karşı duran isimlerin kafalardaki soru işareti ' Ortanın Solu'nun, aşırı soldan farkı nedir?" sorusuydu. Muhalifler bu ayrımın net bir şekilde belirlenmesini ve Cumhuriyetin temellerine dayanan geleneksel parti kültürünün göz ardı edilmemesini istemiştir. ${ }^{32}$ Turan Güneş ve Bülent Ecevit gibi yeni doktrini savunan isimler ise bir ayrışma endişesi taşımadan eleştirileri değerlendirmiş, akımın temellerini sağlamlaştırmaya çalışmıştır. ${ }^{33}$

Ortaya çıtı̆̆ı̆nda gerek sosyal gerekse siyasal içerikli sağlam bir alt yapısı bulunmayan Ortanın Solu akımı, gelen eleştirilerle kendini şekillendirerek geliştirmiştir. Ancak Parti Meclisindeki bu tartışmalar, siyasi değişim ile birlikte parti içi tartışmaların ve hizipleşmelerin kapısını aralayarak tarihe geçecek olan süreci de beraberinde getirmiştir. Ortanın Solu kavramı, genel olarak parti dışından daha ziyade parti içinde çok daha fazla tartışılmıştır. Keza net olarak içi doldurulamayan ve 27 ayrı anlamda tanımlanmaya çalışılan Ortanın Solu deyimi henüz içi doldurulamamış bir slogandan ibarettir. ${ }^{34}$

\subsection{Sekizler Hareketi}

Ortanın Solu akımıyla ilgili sağlanan bir uzlaşı ortamı henüz mevcut değilken parti içi ilk etkili muhalefet grubu Turhan Feyzioğlu tarafindan Sekizler Hareketi ile vücut bulmuştur. ${ }^{35}$ CHP içerisinde "'Sekizler Hareketi' adı verilen grup 1966 senato seçimleri sonrasında ortaya çıkmış ve Turhan Feyzioğlu'nun liderliğini üstlendiği ekiptir. ${ }^{36}$ PM içerisindeki sekiz azadan oluşan muhalif grubun, TBMM'de 63 üyeli destekçi bir grubu vardı. Hareketin parti içerisinde bir muhalif grup olarak doğmasından evvel özellikle ekibin liderliğini üstlenen Turhan Feyzioğlu 1965 seçimleri boyunca Ortanın Solu akımını savunurken Devletçiliğin yeni teşekkülü şeklinde olarak yorumlamış ve Genel Başkan'ın çizgisinde bir yol izlemiştir. Feyzioğlu, CHP Ortanın Solu akımıyla yalnızca Türkiye'deki azınlık bir grubu değil, milyonlarca işçiyi, emekliyi, tüm milleti ve ülkeyi refaha eriştirmeyi gaye edinmiş, bunun için de Toprak Reformu'nun gerekli olduğunu belirtmiştir. ${ }^{37}$ SağKemalizm olarak nitelendirilebilecek görüşe sahip olan Feyzioğlu'nun Ortanın Solunu savunurken Sol fraksiyona antipatisinden kaynaklı olarak özellikle "Ortanın Solu" ifadesini kullanmadığı göze çarpmaktadır. ${ }^{38}$ Keza bu sebeple Feyzioğlu'nun teklif edildiği iddia

Kemal Satır, CHP'de Bunalım, Nüve Matbaası, Ankara, 1972, s.45-46. Esmer, s. 43.

Muammer Erten, Topraktan Parlamentoya, (Yay. Haz: Hakkı Uyar), Yayınlanmamış Çalışma, İzmir, 2005, ss. 113-145.

Esmer, s. 44.

Abadan, s. 161.

Esmer, s. 44.

Muzaffer Sencer, Türkiye’de Siyasal Partilerin Sosyal Temelleri, Geçiş Yayınları, İstanbul, 1971, s.298.

“Çıkarcı ve Komünistler Ortanın Soluna Düşmandır”, Ulus, 13 Eylül 1965. Feyzioğlu’nun Kayseri’deki seçim konuşmasından

Feyzioğlu'nun bu konudaki görüşleri için bakınız: Turhan Feyzioğlu, Atatürk ve Milliyetçilik, Atatürk Araştırma Merkezi Yayınları, Ankara, 1986. 
edilen Ortanın Solunun liderliğini kabul etmesi beklenemezdi. ${ }^{39}$

Sekizler Hareketi'nin ya da 76'ların Ortanın Solu'na karşı açıtan ilk muhalefeti 18. Kurultay'da başladı. ${ }^{40}$ Turhan Feyzioğlu, Turan Şahin, Ferit Melen, Süreyya Koç, Orhan Öztrak, Emin Paksüt, Fehmi Alparslan, ve Coşkun Kırca gibi isimlerin başını çektiği hareket, 1lımlı muhafazakârlığa, liberal sağcılığa dönük orta demokrasi çizgisine yakın bir siyasi görüşe sahipti. ${ }^{41}$ Sekizler Hareketi, Ortanın Solu akımına karşı eleştirilerini çeşitli şekillerde sürdürürken ilk olarak CHP Parti Meclisi bildirisine karşı çıkmış ve "İlk Açıklama ve İthamlara Cevap" adlı bir broşür ile tutumlarını ortaya koymuşlardır. ${ }^{42}$ Sekizler Hareketi Ortanın Solu'na karşı açıktan ilk muhalefeti yaptıkları 18. Kurultay'da istediklerini alamasalar da, Kurultay sonunda yayınlanan bildiriye "CHP sosyalist değildir ve olmayacaktır." ifadesini yazdırmışlardır. Parti içinde yeni tartışmalara neden olan bu ifade özellikle Sol kanat tarafından tepkiyle karşılanmış ve partinin geleceğinin şimdiden belirlenemeyeceği görüşü ifade edilmiştir. Sekizler Hareketi 18. Kurultay'ın ardından mücadelelerine devam etmiş lakin bir sonuç alamamışlardır. 4. Olağanüstü Kurultay'da İsmet İnönü'nün Sekizler Hareketi'ni ağır bir şekilde eleştirmesi Sekizler Hareketi'nin gücünü azaltmakta ve mevcudiyetlerini daha da zora sokmuştur. ${ }^{43}$

4. Olağanüstü Kurultay'ın sonunda Sekizler Hareketi bir kez daha mağlup olmuş ve Abdülkerim Saracoğlu, Ahmet Demiray, Ahmet Onan, Arif Ertunga, Arif Şıhoğlu, Bahri Yasın, Bekir Tınay, Cemal Yavuz, Coşkun Kırca, Emin Paksüt, Enver Bahadırlı, Enver Güreli, Fehmi Alparslan, Fehmi Baysoy, Fenni İslimyeli, Ferit Melen, Fethi Çeliknaş, Hayri Başer, Hilmi İncesulu, Himmet Erdoğmuş, Hüseyin İnceoğlu, Hüseyin Yılmazü, İbrahim Aysoy, İbrahim Ethem Karakapıl1, İhsan Kabaday1, İrfan Solmazer, Kemali Beyazit, Mahmut Çetin, Mahzar Basa, Mehmet Pırıltı, Muammer Obuz, Mustafa Dinekli, Mustafa Uyar, Necip Seyhan Nizamettin Özgül, Nurettin Ardiçoğlu, Orhan Öztrak, Rafet Eker, Ruhi Soyer, Sakıp Hatimoğlu, Sedat Çumralı, Süreyya Koç, Şevket Raşit Hatiboğlu, Turhan Feyzioğlu, Turhan Şahin, Vefa Tanır, Zarife Koçak, Zeki İslam, gibi isimler de partiden ayrılmıştır. ${ }^{44}$ Sekizler Hareketi'nin partiden ayrılmasının ardından parti kurma çalışmaları başlamış, akabinde Güven Partisi(GP)'nii ${ }^{45}$ kurmuşlar ve Ortanın Solu'na parti dışından muhalefet etmeye devam etmişlerdir.

\subsection{Ortanın Göbekçileri}

1969 seçimleri öncesinde Ortanın Solu'nu desteklerken İnönü’nün Ortanın Solu üzerindeki etkisinin azalmasıyla ve 1969 Seçim Bildirgesi'nin ardından Kemal Satır ve

39 Esmer, s. 45.

40 Emre, 94.

41 Bahri Savc1, “ 8'lerin Yeri ve Yolu”, Akis, 13 Mayıs 1967.

42 Sekizler Gurubu, İlk Açıklama ve Bazı İthamlara Cevap, Doğuş Matbaacılık, Ankara, 1967, s.1-2.

43 İsmet İnönü, İnönü Ortanın Solunu Anlatıyor CHP Nedir? Ne değildir?, CHP Genel Sekreterliği Yayınlar1, Ankara, 1967, s.18.

44 Esmer, s. 46.

45 Güven Partisi, Cumhuriyet Dönemi Türkiye Ansiklopedisi, c.8, İst.1983. 
Nihat Erim gibi CHP'nin ağır topları Ortanın Solu'na karşı muhalif bir tutum izlemeye başlamıştır. Zira 1969 Seçim Bildirgesi ile birlikte Bülent Ecevit'in adının ön plana çıkması Ecevit'ten daha deneyimli ve kıdemli partilileri rahatsız etmiş ve bu durum "Ortanın Göbekçileri”"46 adı verilen Kemal Satır'ın liderliğini üstlendiği muhalefetin başlamasında etkili olmuştur. İnönü’nün Ortanın Solu hareketi üzerindeki etkisinin azalmasıyla birlikte İnönücü kesimi harekete geçirmiştir. Bu gurubun arasındaki en hararetli tartışma 18 Ekim 1968 'de yapılacak olan 19. Kurultay öncesinde yaşanmıştır. 14 Ekim günü yapılan Parti Meclisi toplantısında Muammer Aksoy, Ortanın Solu'nu destekleyenleri etkisizleştirmeye yönelik olarak Kemal Satır'ın iş çevreleriyle işbirliği yaptığı yönünde bir iddiada bulunmuştur. Bu iddia parti meclisinde büyük tartışmalara yol açmıştır. Muammer Aksoy tarafindan ortaya atılan bu iddia yalanlanmamıştır. Fakat İnönü bu iddia üzerine kürsüye çıkarak "Bu iddia haksız ve mesnetsizdir" şeklinde bir ifade kullanmıştır. ${ }^{47}$ İnönü’nün Kemal Satır'ı kollayan bu tavrı, aslında Ortanın Solcuları ile İnönü arasında başlayacak olan ayrılığın bir kıvılcımı olarak değerlendirilebilir. Yaşanan tüm bu olayların ardından 18 Ekim 1968 tarihinde 19. Kurultay'a gidilmiştir. Toplanan kurultayda İnönü bir açılış konuşması yapmış ve konuşmasında partide halen Ortanın Solu açılımına inanmayanların olduğu yönünde açıklamalarda bulunmuştur. Konuşmasının devamında da "Biz sosyalist parti değiliz, Cumhuriyet Halk Partisi'yiz" ${ }^{48}$ şeklinde bir ifade kullanarak parti içindeki geleneksel denge kurucu yönünü yeniden göstermiştir.

Ortanın Göbekçileri'nin Ortanın Solu'na karşı ilk itirazları seçim bildirgesi ve MYK'nın uygulamaları üzerinedir. Bildiride dikkatleri toplayan unsur "Toprak işleyenin, su kullananın" anlayışıdır. Bu anlayışın yasa dışı olduğunu savunan '"göbekçiler', mülkiyet hakkı ihlalinin söz konusu olduğunu belirtmiştir. ${ }^{49}$ Satır, eskiden Ecevit'e ve savunduğu Ortanın Solu fikrine karşı bir inancının olduğunu, ancak bu inancın bilhassa 1969 Seçimleri ile sarsıldığını belirtmiştir. ${ }^{50}$ Göbekçilerin ikinci itirazı ise Atatürk Devrimleriyle ilgili Ecevit' in verdiği demeçlerdir. Bilhassa Erim “Atatürk'ün kurduğu partinin Genel Sekreteri Atatürk'ü eleştiremez" çıkışıyla Ecevit'in demeçlerini sert bir biçimde yermiştir. Merkez Yönetim Kurulu'nun, partiyi yönetemediği, birliği ve huzuru bozacak tarzda çalıştığ1, fonksiyonunu kaybeden yönetimin bazı zamanlar 5 kişilik çoğunlukla karar aldığına dair iddialar da yükselmiştir. ${ }^{51}$

Genel Sekreterin belirli kişilerin etkisi altında kalarak partiyi sola çekme düşüncesiyle hareket ettiği yorumları ve partinin altyapı devrimciliğine geçişi hakkında alınan bir karar olmamasına rağmen, bu yönde konuşmaların yapılması da rahatsızlık uyandırmıştır. 'Düzen değişikliğii' meselesinde ise Anayasa'nın tam işletilmesi ve Toprak Reformu'ndan farklı olarak bir açılımın yapılmamış olması, düzen değişikliğinin içeriği hakkındaki soru işaretlerini de giderememiştir. Muhalifler mezkur akımın yenilik anlamında farklılık vaat etmediğini eleştirirken özellikle Genel Sekreterin, bazı yerlerde köylülerin toprak

46 Cemal Fedayi, 'Ortanın Solu Akımı’, Liberal Düşünce, kış 2004, s.169.

47 "Parti Meclisinde Gerginlik",Cumhuriyet, 15 Ekim 1968, s.1

48 CHP 19. Kurultay Bildirgesi, (İnönü’nün Açılış Konuşması) Ulusal Basımevi, Ankara, (20 Ekim 1968)

49 Esmer, s. 49.

50 Cumhuriyet, 6 Temmuz, 1970, s. 7.

51 CHP 20. Kurultayı Parti Meclisi Raporu, Ulusal Basımevi, Ankara, 3 Temmuz 1970, s.65-67. 
işgallerini bir devrimci eylem gibi gösterdiğini ve MYK'nın yanlış kararlarının partiye oy kaybettirdiğini savunmuştur. Seçimlerde beklenilen sonuçların alınamaması muhalefetin sesini yükseltirken partide başlayan dip değişimin pratikte uygulanabilecek bir tablo sergilememiş olması başarısızlığın en önemli etkeni olarak değerlendirilmiştir. Ayrıca parti içerisindeki eski kadronun varlığını devam ettirmiş olması da yenilik hareketinin kamuoyu nezdinde taban bulamamasina sebep olmuştur. ${ }^{52}$

CHP kadrolarındaki yenilenme 1969 Seçimlerinde başlamış ve seçimler sonucunda toplam 143 milletvekilinden 88 'i ilk kez meclise girmiştir. ${ }^{53}$ Yeni seçilen milletvekillerinin Ortanın Solu'nu desteklemesi parti içindeki tartışmaları arttırırken PM'deki iç mücadeleyi alevlenmiştir. ${ }^{54}$ Akabinde Ecevit grubu ve Kemal Satır grubu arasında bir düello olarak tarihe geçen 20. Kurultay'ın erken toplanması kararı alınır. İnönü'nün desteğini bekleyen Kemal Satır grubu İnönü'nün tarafsız açıklamaları karşısında beklenmedik bir şok yaşar ve kurultaya mağlubiyet ile başlar. ${ }^{55}$ Kurultayda MYK'nın usulsüz uygulamalarına rağmen "Ecevit giderse Ortanın Solu da biter" korkusu baskın gelmiş, il delegeleri Ecevit ve grubunu desteklemiştir. ${ }^{56}$

20. Kurultay, Ortanın Solu grubunun mutlak bir galibiyeti ile sonuçlanmıştır. Genel Başkanın isteğiyle Kemal Satır ve Kemal Demir, Parti Meclisine seçilmiştir. Ancak daha sonrasında, Parti Meclisinden istifa eden Satır ve Demir bu defa daha katı bir muhalif tavır ile parti içindeki mücadelelerine devam etmiş̧ir. 12 Mart sonrası dönemde Bülent Ecevit ile arası açılan Genel Başkan İsmet İnönü bu dönemde Kemal Satır grubuna destek vermeye başlamıştır. Ancak Ortanın Solu ekibi artık güçlenerek parti örgütüne hâkim olmuştur. Zira sonraki dönemde Genel Başkan İnönü’nün ağırlığı dahi Ortanın Solu ekibini pasifize etmeye yetmeyecek hatta genel başkanlık koltuğu bile değişecektir. Kemal Satır'ın yorumuyla bir reddi miras davranışı içerisinde hareket etmekte olan Ecevit, Devrimlerin taklitçilikten ibaret olduğunu düşünmekte, hakiki halkçı tipinin Ortanın Solu hareketinde barındığını ve cumhuriyet devrinde halkın yöneticileri benimsemediğini, yöneticilerinde ise halka tepeden baktıklarını düşünmektedir. ${ }^{57}$ Kurultay sonrası Kemal Satır ve ekibi parti içindeki mücadeleyi bırakmak istemeseler de kurultay sonrası Parti Genel Merkezi'ni ve Parti Meclisi'ni tamamen kaybetmişlerdi. Muhalefete devam etmek için ise tek çare parti gruplarına yönelmekti. Dolayısıyla Ortanın Göbekçileri grup başkanvekilliklerini ele geçirmişlerdir. Nihayetinde 20.Kurultay her ne kadar Ortanın Solu'nun PM'de mutlak anlamda bir zaferi ile sonuçlansa da muhalefetin partiyi Ortanın Solu'na bırakmayacağı ve mücadelenin bir süre daha devam edeceğinin göstergesidir. ${ }^{58}$

Ortanın Solu grubu parti içinde yükselen bu muhalefet hareketini; parti içinde bulunan siyasal sağcıların, Türkiye'deki zaruriyet teşkil eden devrimlerin, ancak bir sivilasker seçkinler yönetimi tarafından jakoben bir tavırla gerçekleşebileceğine inananların ve

52 Esmer, s. 254.

53 Esmer, s.255.

54 Ahmet İsvan, Başkent Gölgesinde İstanbul, İletişim Yayınları, İstanbul, 2002, s.32.

55 Esmer, s.52.

56 İsvan, s.57.

57 Esmer, s. 53.

58 Cumhuriyet, 10 Temmuz 1970, s.1. 
partiyi de bu tarz bir anlayışın aracı konumuna taşımak niyetinde olanların son çırpınışları olarak değerlendirmiştir. Kemal Satır grubu parti içi mağlubiyetin ardından Genel Başkan İnönü'nün istifası ile CHP'den ayrılıp, sonraları GP ile bir araya gelerek 'Cumhuriyetçi Güven Partisi(CGP)', adıyla birleşecekleri Cumhuriyetçi Parti(CP)'yi kurmuştur. ${ }^{59}$

\section{3. Üçüncü Dünyacılar}

' 'Üçüncü Dünyacılar' ' partideki muhalif sesler arasında yer yer farklı gruplara verilen ismin karşılığı olmuştur. İlk olarak 1967 yılında Muammer Erten, Hayrettin Uysal, Mehmet Ergül ve Hüdai Oral gibi isimlerden mütevellit olan hareket daha sonra 1974 Kurultay1'nda önceleri Baykalcılar olarak tanınmasına karşın Üçüncü Dünyacılar adıyla yeni bir ekibin etrafında toplanmış ve Karadenizliler ekibi ile bir olmuştur. Üçüncü Dünyacılar'ın ilk oluşumu "Orta Solcular'" ve "'Radikal Sol kanat'" arasında denge sağlayan bir unsuru oluşturmakla birlikte sol kanada yakın ve İsmet İnönü'ye de bağlıdır. ${ }^{60}$ Zira Bülent Ecevit' in yükselişine kadar Ortanın Solu'nu desteklemiş olsalar da Ecevit'in yıldızının parladığı zamanlarda aralarında anlaşmazlık çıkmıştır. Aslında MuammerErten'in kastettiğioportünist tutum; özellikle doğu mitingleri esnasında CHP genel merkezinin TíP'in düzenlediği doğu mitinglerine katılınması yönündeki parti örgütüne göndermiş olduğu genelgedir. CHP'nin kendi insiyatifi dışında gelişen olayların peşinden gitmemesi gerektiğini söyleyen Üçüncü Dünyacılar, MYK' da yaptıkları baskı neticesinde genelgenin yürütülmesini engellerler ve böylelikle muhalefete dahil olurlar. Parti içerisindeki muhalefet anlamında çok fazla ses getiremeyen ve zamanla etkilerini kaybeden Üçüncü Dünyacılar daha sonra istifa ederek CHP'den ayrılmışlardır. ${ }^{61}$

\subsection{Sosyalist-Sol Grup}

Yöntem hususunda Ortanın Solu akımıyla zıt düşen bir başka grup ise Sosyalist-Sol ve ya Ulusalcı Sol ekibiydi. Orhan Kabibay'ın önderliğini yaptığı ekip, sandık iradesiyle sosyalist bir devrimin hayat bulamayacağını, sosyalist inkılabın ancak asker-bürokrat kesiminden oluşan bir kadroyla “tepeden inmeci" bir usul ile gerçek olabileceğine inanıyordu. Ordu içerisinde de mensupları bulunan bu gruba göre CHP bu askeri hareketin destekçisi olmalıydı. Nermin Neftçi, "CHP'li Sosyalistler” şeklinde adlandırılan CHP içerisindeki bazı isimlerin "Cici Demokrasi" ifadesiyle demokrasiyi küçümsediklerini kaleme almış olduğu anılarında aktarmıştır. ${ }^{62} \mathrm{Bu}$ dönemlerde Doğan Avcıŏlu ise tüm Ortanın Solu karşıtlarına destek vermiş, özellikle Orhan Kabibay'ın başını çektiği Sosyalist-Sol grubuna yakın durmuştur. 1960'lı yıllarda Türkiye'de Sosyalist Solun güç kazanarak kitleselleşmeye başladığı bu dönemde, 1969 sonlarında Avcıoğlu tarafından çıkartılan Devrim, Ortanın Solu'na muhalif yayınlar ile döneme damgasını vurmuştur. "Cici Demokrasi" olarak adlandırdığı mevcut düzen yerine "bürokratik devrim" tezini savunan ve askeri müdahaleyi çözüm olarak gören Avcıoğlu, en sert tenkitlerini Ortanın Solu akımına ve Bülent Ecevit’e

59 Haluk Ülman-Ahmet Yücekök, “CHP'deki Değişikliğin Gerçek Anlamı”, Özgür İnsan, Sayı 1, 1 Haziran 1972. Esmer, s. 53.

60 Esmer, 48.

61 Esmer, 49.

62 Nermin Neftçi, Demokrasinin Kilittaşı Anılar, TESAV Yayınları, Ankara, 1997, s.85. 
yöneltmiştir. ${ }^{63}$

\subsection{Ortanın Solu Ekibi: Forum Grubu, Hzzlı Sol, Marksist Grup}

CHP içerisinde Ortanın Solu akımını benimsemiş farklı cenahlardan oluşan gruplar, hareketin başına bir isim ararken parti tavanının dikkatini çekmeyecek ve Genel Başkan İnönü'nün de rahatsız olmayacağı bir karakter olan Bülent Ecevit, uzlaşmacı kişiliğinin yanı sıra farklı kesimler içerisinde koordinasyon sağlayan liderlik vasfı ile ortaya çıktı. Ecevit'in etrafında olarak Üçüncü Dünyacılar, Kamil Kırıkoğlu, Şükrü Koç, Rauf Kandemir, Süleyman Genç ve Selahattin Hakkı Esatoğlu, Abdullah Baştürk, gibi isimlerden oluşan "Hızlı Sol”, Cemal Reşit Eyüboğlu önderliğindeki Marksist Grup ve Ecevit'in yakın çevresinde bulunan İbrahim Öktem, Turan Güneş, İlyas Seçkin ve Orhan Birgit'ten oluşan ve 'Forum Grubu' (Tayfa Grubu) olarak adlandırılan çekirdek kadro kümelenmişti. ${ }^{64} \mathrm{Bu}$ grupların birleşimiyle tezahür eden Ortanın Solu ekibi daha sonra kendi içinde polarize olacak ve tavanda gerçekleşen bu yol ayrılıkları, üniversiteli genç bilim adamlarının yeni bir beyin takımı oluşturmasına zemin yaratacaktır. ${ }^{65}$

\subsection{Ortanın Solu İçerisindeki Ayrılıklar}

1967 yılında MYK ile anlaşmazlığa düşerek Ortanın Solu ekibiyle yolları ayıran ilk grup Üçüncü Dünyacılar ekibi olmuştur. 1969 'da gündem olan siyasi af tartışmaları sebebiyle Muammer Aksoy, Jale Candan ve Nermin Abadan Parti Meclisinden istifa etmiştir. $\mathrm{Bu}$ isimlerin muhalif tavır almaları, daha önceden entelektüel kimlikleri ile Ortanın Solu teorisine katkıda bulunmuş olmaları açısından önemli bir husus taşımaktadır. Özellikle Kadın kolları başkanlığı yapmış olan Jale Candan, Ortanın Solu akımının parti örgütü tarafından benimsenmesinde önemli rol oynarken Akis Dergisi`nde Bülent Ecevit ve Ortanın Solu ile ilgili yazdığı yazılarla kamuoyu oluşturmuştur.

İsmet İnönü'nün 1972 yılında Genel Başkanlığı bırakmasıyla İnönücüler olarak adlandırılan, Necip Mirkelamoğlu Seyfi Sadi Pencap, Lebit Yurtoğlu, Ali İhsan Gögüş ve Sezai Orkunt ve Mustafa Kaftan partiden istifa etmiştir. Bu isimler arasında özellikle Lebit Yurdoğlu, 18. Kurultay'da "Anahtar Metodu" ile Ortanın Solu ekibini MYK'da sirtlayan isim olurken Ali ihsan Göğüş ise Ortanın Solu'na Akis Dergisi'nde yazdığı yazılarla akımın gelişimine önemli katkılar sunmuştur. 1973 seçimlerinin ardından Mülkiyeliler grubunu da içine alan bir parçalanma süreci yaşanırken sol kanadın önemli isimlerinden biri olan ve Bülent Ecevit'in Genel Başkan olmasında önemli bir payı bulunan Kamil Kırıkoğlu, Cumhurbaşkanlığı seçimleri esnasında tartışmalarla Rahşan Ecevit'in başkanlığındaki Köylü Derneklerinin parti ile organik bir bağı olmadığ 1 halde parti için faaliyette bulunmasını istememesinden dolayı Genel Sekreterlikten istifa etmiştir. ${ }^{66}$

\subsection{Karadenizliler-Baykalcılar Mücadelesi ve Demokratik Sol Tartışması}

Kamil Kırıkoğlu'nun istifasının ardından Genel Sekreterlik görevine yeni gelen

63 Doğan Avcığlu, “İnönü’nün Konuşmaları”, Atatürkçülük, Milliyetçilik, Sosyalizm, İleri Yayınları, İstanbul, 2006, s. 57.

64 Esmer, s. 54.

65 Esmer, s. 54.

66 Kamil Kırıkoğlu, 'Kavganın Nedeni”, Yankl, 9-15 Aralık 1974. 
Orhan Eyüboğlu'nun dahil olduğu "Karadeniz Cuntası" da parti içi mücadelenin içerisinde yer almaya başladı. İstanbul İl yönetimi Karadeniz Cuntası olarak isimlendirilen bu grup için Hizbi tanımlamasını da kullanmıştır. ${ }^{67}$ 22. Kurultay'da Kamil Kırıkoğlu'nun önderliğindeki sol kanat mağlup olurken Karadeniz Cuntası, Orhan Eyüboğlu ve Ali Topuz gibi isimlerle MYK'da etkinliğini arttırdı. Bu yeni durum Baykalcılar ve Karadeniz Cuntası'nın mücadelesine kapı araladı. İstanbul İl Teşkilatı, parti içerisindeki delege sayısı nedeniyle kurultaylardaki neticenin şekillenmesinde büyük paya sahipti. Bundan dolay1 parti içindeki iktidar mücadelesinde önemli bir nüfuza sahip olan örgütün yönetimini Karadenizliler Cuntası olarak bilinen Ali Topuz başkanlığında; Orhan Eyüboğlu, Mahmut Erdem, Aytekin Kotil, Ali Turgan, Necdet Uğur, Yalçın Görsel, Metin Tüzün, Yunus Kara, Tarhan Erdem ve Erol Ünal gibi isimler meydana gelen ekip oluşturuyordu. Karadenizliler başından beri Ecevit'in yanında yer almış ve Genel Başkan İnönü'ye parti içinde karşı duran ilk il yönetimi olmuştur. Bu sebeple Ali Topuz ve Orhan Eyüboğlu gibi ağır toplar 1973 seçimlerinde parlamentoya girmiş lakin il örgütü ile olan temaslarını koparmayarak Aytekin Kotil'in İl başkanı olmasını sağlamışlardır. ${ }^{68}$

Usulsüzlük iddialarıyla anılan 1974 İl Kongresinde, Karadenizliler Cuntası ile mücadeleye girişen ve kendisi de bir Karadenizli olan Faruk Erginsoy, Ortanın Solu'nu savunan Aytekin Kotil ve Ali Topuz ekibine karşı Demokratik Sol'u savunmuş, ancak İ örgütündeki bu çekişmeyi, Demokratik Sol Grubu kaybetse de Demokratik Sol, parti içindeki teorik alanda Ortanın Solu'nun yerini almaya başlamıştır. ${ }^{69} 1974$ İl Kongresi'nin ardından 1976 İl Kongresinde de gruplaşmaların mücadelesi sürmüştür. Daha öncesinde Ali Topuz ve ekibinin yanında olan Baykalcılar, bu defa Faruk Erginsoy ve Demokratik Sol Ekibini desteklerken Deniz Baykal da il yönetimine karşı olan ekibin başını çeken lider oldu. Demokratik Sol'u savunan Erginsoy'un grubu 1976'da bir mağlubiyet yaşamış olsa da kongrede ağırlık basan taraf Demokratik Sol olmuş ve Demokratik Sol'un iktisadi bir politik program olduğunun altı çizilmiştir. ${ }^{70}$

İstanbul İl Örgütüınde bunlar yaşanırken Ankara İl Örgütü`nde Rauf Kandemir, Ali Dinçer ve Vedat Dalokay gibi isimler ön plana çıkmış ve sol kanatla olan mücadelesinde İstanbul örgütüne destek olmuştur. Ancak daha sonrasında iki örgüt arasında bir mücadele başlamıştır. Ayrıca Ecevit'in kalesi İzmir'de de bilhassa 1973 yerel seçimleri öncesinde Ecevit'in desteğini alan İhsan Alyanak ön plana çıkan isim olmuştur. Parti içindeki alt gruplar arasında bu denli bir çatışma ortamı hakimken Bülent Ecevit, güç odağı çevreleri takip ederek zamanla egale etmiştir. Parti ve il örgütleri içerisindeki nüfuz mücadeleleri 1980 yılının ortalarına kadar sürerken parti merkezinde Baykalcılar ve Karadeniz Cuntası'nın savaşı devam etmektedir. İki ekip, 1976 il kongresi öncesinde MYK'da karşı karşıya gelmiş ve çatışma ortamının 5'ler olayı ile patlak vermesinin ardından Deniz Baykal, Erol Çevikçe, Adil Ali Cinel, Tankut Akalın ve Haluk Ülman MYK'dan ayrılmıştır. ${ }^{71}$ 23. Kurultay'a

67 İsvan, s.259.

68 Esmer, s. 56. Hakkı Uyar, İstanbul'un “Tom Alaka”sı ya da Karadenizli Bir Politikacı: Aytekin Kotil (1934-1992), Yayınlanmamış Çalışma, İzmir, 2001.

69 Uyar, s. 35.

701976 Cumhuriyet Halk Partisi İstanbul İl kongresi, 11-12 Eylül Fitaş Sineması.

71 Hikmet Bila, Sosyal Demokrat Süreç İçinde CHP ve Sonrası, Milliyet Yayınları, İstanbul, 1987, s. 417. 
kadar il kongreleriyle parti merkezi arasındaki mücadele devam ederken 23. Kurultay'da Ecevit'in parti içindeki gütmüş olduğu siyaset neticesinde Orhan Eyüboğlu yeniden genel sekreterlik koltuğuna oturmuş, Baykalcılar için ise durum zorlaşmıştır. 11 bağımsız milletvekili ile DP ve CGP'nin desteği sayesinde kurulan 42. hükümet döneminde Ecevit ve Eyüboğlu'nun arası bozulmaya başladığında Deniz Baykal ve Ali Topuz'un ekipleri beraber yürümeye başlamıştır. Bu nedenle 24. Kurultay, Ecevit açısından zor geçerken parti içerisinde ise yeni bir liderlik mücadelesinin başlangıcına neden olmuştur. 14 Ekim 1979 tarihinde yapılan ara seçimlerin sonucunda CHP'nin oyunun \%41'den \%29'a düşmesi ile parti içerisindeki yeni liderlik yarışı, hız kesmeden daha da şiddetlenmiştir. Bu oy kaybında hükümetin başarısız politikalarının yanı sıra parti içindeki iktidar mücadelelerinin de bir hayli etkisi olmuştur. Parti içindeki bu hizipleşme, iki ekipten biri galip gelene kadar devam edecek ve Nihayetinde 12 Eylül Askeri müdahalesi ile ancak son bulacaktır. ${ }^{72}$

\section{Ortanın Soluna Karşı Parti Dıșı Muhalefet}

CHP'de Ortanın Solu ile başlayan bu siyasal metamorfoz sürecine, diğer partiler de sessiz kalmamıştır. Diğer partiler tarafından ilk zamanlar tepki ile yaklaşılan bu ideolojik kimlik arayışı, sonraları onlar için de kendi yerlerini bu biçimde ideolojik bir tanımlama ile şekillendirme zarûrîyeti doğurmuştur. Özellikle sağ partiler için geçerli olan bu durum, sol muhalefette ise CHP'nin sol'a açılımının kendilerine meşruiyet sağlaması açısından önce olumlu karşılanmış, ancak daha sonra kendileri için bir tehdit olarak görülmüştür.

\subsection{Parti Dışı Sol Fraksiyonun Ortanın Soluna Karşı Muhalefeti}

Ortanın Solu akımı tartışılmaya başlandığı ilk zamanlar, sol gruplar tarafindan olumlu karşılanmış, Aydınlık, Yeniçağ, Devrim, Türk Solu, Ant gibi özellikle sol fraksiyonun önemli yayın organları, hareketi Türk Solu penceresinden mutena bulmuştur. Bu dönemde Türkiye Komünist Partisi(TKP)'nin propaganda aracı olarak kullanılan Bizim Radyo ise Bülent Ecevit ve Ortanın Solu'nu destekleyen yayınlar yapmıştır. ${ }^{73}$

TİP de ilk zamanlarda Ortanın Solu'na karşı olumlu bir tutum sergileyerek sağ'a karşı "Milli Kurtuluş Cephesi Tezi" ${ }^{74}$ kapsamında CHP'ye bir ittifak kurmayı önermiştir. Lakin olumlu karşıllk görmeyen bu öneri, Ecevit tarafından "TİP'in tutumunu tehlikeli buluyoruz" 75 şeklinde reddedilmiştir. Bunun üzerine TİP cephesinde tepkiler başlamışken 1969 yılında eski DP'lilerin affının gündeme gelmesi ile birlikte sol cenahın tenkitleri giderek şiddetlenmiştir. Bu süreçten sonra Ortanın Solu'nu kendileri için bir engel atfeden sol kesim, Ortanın Solu'nu bir halk dalkavukluğu olarak nitelendirmiştir. Ortanın Soluna karşı yönelen eleştirileri okları lider Bülent Ecevit'e de yönelmiş, Ecevit, Mülkiye Cuntası'nın boyunduruğu altına girmekle suçlanmıştır. Ecevit' in genel başkanlığı ile birlikte eleştiriler hat safhaya ulaşırken 1973 seçim bildirgesi çoğu yönden yetersiz bulunmuş hatta sol gruplara göre 1973 bildirgesi sol oyları toplamak adına yapılan siyasi bir hile olarak değerlendirilmiştir. Köy-Kent ve Toprak Reformu gibi konularda eleştiri yağmuruna

72 Esmer, s. 58.

73 Esmer, s. 59.

74 Doğan Avcıŏlu, “ Sosyalist Gerçeklik”, Yön, Sayı 38, 12 Eylül 1962.

75 Ulus, 18 Ekim 1967. Ecevit'in TİP’e ilişkin görüşleri için bknz. Emre, s. 99-100. 
tutulan CHP, sol fraksiyon tarafından samimi olmamakla suçlanmıştır. ${ }^{76}$

Döneme damga vuran yayınların başında gelen Yön dergisinin, 1965 Seçimlerinden evvel yapmış olduğu değerlendirmeler çerçevesince CHP'yi oldukça eleştirdiği görülmektedir. İffet Aslan'ın yorumuna göre Türkiye'deki siyasi partiler arasında doktriner bir vasfa sahip olan tek parti TIP'dir. Bu yaklaşımda siyasi partiler birer ideoloji yelpazesi halinde görülürken en geniş yelpaze dilimine sahip olan parti ise CHP olarak değerlendirilmiştir. CHP başat kesimin özellikleri açısından sosyal adaletten yanadır ve kendisini merkezin solunda konumlandırmasının anlamı budur. İffet'e göre doktrin ve ideoloji çatışmalarının belirleyeceği 1965 Seçimleri Türk siyasetinde önemli bir yer tutarken $^{77}$ Yön, CHP'yi destekler mahiyette şöyle bir yazıya yer vermiştir:

“ Türkiye’yi bugünkü(Eylül 1965) bağımlı durumunda tutmak için her türlü tertibe başvuracak güçlerin imkânlarını küçümsemek, tarihi bir hata teşkil edecektir. Kesinlikle bilmek gerekir ki, satılmışlar ile satılmamışlar arasındaki mücadele çok çetin olacaktır. Mücadelenin başarısı her şeyden önce, en geniş bir milliyetçiler birliğinin kurulmasına bağlıdır. Bu bakımdan sosyal yapı itibariyle CHP büyük önem taşımaktadır. CHP lideri İnönü, tarihi kişiliği ve toplumun sağlam kuvvetleri üzerindeki prestiji sayesinde, partisini aşan bir çıkışla, ekonomik bağımsızlık yolunda ilk olumlu adımları atmıştır. Bu çabalar yeterli ya da yetersiz bulunabilir. Ama dış politikada tek taraflı ilişkilerden çok taraflı ilişkilere yöneliş ve petrol kanunu değişikliği hiç şüphesiz doğru yolda alınmış tedbirlerdir. Üstelik CHP, anayasayı çiğnemek pahasına, sosyalist hareketi kaba kuvvetle ya da kanunları zorlayarak susturmak isteyen büyük siyasi güçlerin karşısında şimdiye kadar anayasa düzeninin savunuculuğunu yapmıştır. Bu durumda CHP ile AP'ni aynı sepete koymak, bir CHP-AP Koalisyonu'nun zeminini hazırlamak anlamına gelecektir. Mevcut şartlar altında bunun, sosyalistlerin işleyebilecekleri en büyük hata olacağı inancındayız." 78

Ortanın Solu akımı ile Yön arasında, belirlenen hedefler açısından büyük benzerlikler olsa da; iki grup arasında yaşanan tartışmanın temeli, hedefe ulaşma yolundaki uygulama ayrımına dayanmaktaydı. ${ }^{79}$ Sol Kemalizm çizgisinde olan Yön-Devrim grubu açısından ordu büyük önem arz etmekteydi ve nihai hedef olan devrime ulaşma açısından Türkiye'nin sosyolojik yapısında ara tabakalar denen kesim son derece mühimdi. Keza Avcıoğlu bu durumu Türkiye'nin sınıfsal gelişmişlik düzeyiyle ilişkilendirmiştir. Avcıoğlu'na göre Türkiye'deki sınıf ayrımı, kutuplaşma ve Marksist uzlaşmazlık, Batı'daki kadar keskin değildir. Zira Türkiye pre-kapitalist bir yapıya sahiptir. Bu bakımdan Yön çevresi açısından önem arz eden ordu; nihai hedef olan devrimin nesnel zeminini oluşturmada çok önemlidir. Yön'ün etrafında şekillenen aydınlara göre de bu zinde kuvvetler kurtarıcı bir özelliğe sahiptir. ${ }^{80}$ Ecevit ise ordunun siyasete karışmaması gerektiğini belirtmiş ve 1971 Muhtırası'na açıktan ve sert bir şeklide karşı çıkarak net bir tavır sergilemiştir. YönDevrim cenahı ile Ortanın Solu arasındaki bir diğer derin fikri ayrım ise sol kavramının

\footnotetext{
76 Ahmet Kardam, CHP Nedir? Ne Değildir?, Ülke Yayınları, Ankara, 1976.

77 İffet Aslan, "Seçimler Arifesinde Siyasi Partilerin İdeolojik Görüntüleri”, Yön, 11 Haziran 1965, s.7.

78 “Seçimler ve Yön”, Yön, 10 Eylül 196, s.4.

79 Emre, s. 140-142.

80 Doğan Avcıŏlu, "Bir Sosyalist Stratejinin Esasları", Yön, 14 Ekim 1966, s.9.
} 
içeriğine dair gelişmiştir. Doğan Avcıoğlu'nun yorumuyla sol'dan anlaşılması gereken aslında sosyalizmin ta kendisidir. Avcıoğlu, sosyalizmi mutlak gerçek olarak görmüş ve bütün sosyalist akımların aynı sosyalist idealden beslendiğini vurgulamıştır. ${ }^{81}$

CHP'nin NATO ve Ortak Pazar'a karşı tutumu da sol gruplarca eleştirilmiş ve sol kesim, CHP'nin tutumunu salt sosyalist memleketlere değil, aynı zamanda bağımsızlık savaşı güden toplumlara ve 3. Dünya Ülkelerine yönelik saldırgan bir tavır olarak yorumlamıştır. "Akgünlere" başlıklı CHP'nin seçim bildirgesi de sert eleştirilerin hedefi olurken eleştirilerin özünü ise CHP'nin eleştirdiği tekelciliği ve tekelciliğe karşı çözüm olarak sunduğu 'serbest rekabeti' kategorize edememesi oluşturmuştur. Sol gruplara göre CHP, serbest rekabet kapitalizmi ile tekelci kapitalizm arasında bulunan bağlantıyı görememiş, iki yaklaşımı birbirlerine zıt olarak değerlendirip çağı yakalama söylemiyle tekellere karşıt durarak serbest rekabeti savunmuştur. ${ }^{82}$ Ayrıca CHP'nin seçim bildirgesindeki ekonomik kilit noktalarını kamulaştırmaksızın, ulusal sanayiyi gümrük duvarlarıyla korumadan, milli endüstriyi uluslararası tekellerle rekabet edebilecek hale getirme düşüncesi yine sol kesime göre tam bir hayalciliktir. Seçim bildirgesinin bir taraftan Ulusal Burjuvaziyi temsil etme iddiası bulunuyorken diğer taraftan da Ortak Pazar'a tam üye olmayı hedeflemesi, sol'a göre büyük bir çelişkidir. ${ }^{83}$

\subsection{Parti Dışı Sağ Fraksiyonun Ortanın Soluna Karşı Muhalefeti}

CHP'nin 1965 yılında Ortanın Solu'nda olduğunu açıklamasıyla beraber să̆ partiler tarafında Ortanın Solu'na karşı doğal bir muhalefet vücut buldu. Yeni Türkiye Partisi(YTP), Adalet Partisi(AP), Cumhuriyetçi Güven Partisi(CGP), Cumhuriyetçi Köylü Millet Partisi(CKMP), Millî Nizam Partisi(MNP) gibi sağ eğilimli partiler arasında sağ'ın en büyük partisi olan Adalet Partisi, Ortanın Solu'na karşı sağ gruptaki muhalefet liderliğini üstlenmişti. CHP'de Ortanın Solu ile birlikte başlayan ideolojik kimlik tartışmaları, AP'nin de kendisini siyasi yelpazenin sağında tanımlamasına neden oldu. Sol ve sağ kavramlarının tabiatında bulunan çatışma mantalitesi, tabii bir biçimde iki kavramı birbirine muhalif kılarken tartışmayı eşitlik, özgürlük, adalet, iktisat gibi konular üzerine çevreledi. İki parti arasında başlayan tartışma ortamı, ' 'merkez sol ve merkez sağ arasında yaşanan çatışma" kimliğini kazandı. Merkez sol, eşitlikçi ve özgürlükçü bir tutum izlerken Merkez sağ ise hem özgürlükçü hem de kanun önündeki eşitliği savunmaktaydı. Ancak iki görüş arasındaki fikri yol ayrımı finansal söylemlerdeydi. Sağ görüş, her şeyden evvel Ortanın Solu'nu gizli bir sosyalizm programı olarak lanse etmiş ve CHP'nin Türkiye'nin dış düşmanlarının, içerideki uzantılarına yataklık yaptığını iddia etmiştir. ${ }^{84}$ Mustafa Kemal Atatürk'ün komünizme karşı olduğu iddiasıyla başta TïP'e ardından da CHP'ye yüklenen sağ fraksiyon, savundukları iktisadi tez ile uyuşmayan devletçilik uygulamasını da sert bir biçimde eleştirmiştir. Zira sağ kesime göre; millet olarak kalkınıp gelişmemizin önündeki en büyük engel devletçiliktir ve devletçilik, tek parti döneminden bu ülkeye kalan kötü bir hastalıktır. Devrin koşulları içerisinde bir zaruriyet teşkil eden bu eski anlayışın; mevcut

\footnotetext{
81 Doğan Avcıŏlu, "Sosyalizm Anlayışımız", Yön, 22 Ağustos 1962, s.3.

82 Esmer, s. 61. Kardam, s. 35.

83 Kardam, .s.72.

84 “TỉP’in İç Yüzü”, Ortam, Sayı 6, 1 Mayıs 1965.
} 
nüfus artış1 ve özel teşebbüsün kaydettiği ilerlemeler sebebiyle acilen terk edilmesi bir mecburiyettir ${ }^{85}$ Devletçiliğe karşı özel girişimi savunan sağ cenah, devletin patronluğa soyunması akabinde işçinin itiraz hakkının kalmayacağını ve daha fazla sömürüleceğini ifade etmiş ve ayrıca ${ }^{86}$ Toprak Reformu'ndan ziyade hiç kimseyi mağdur etmeyeceği iddiası ile Zirai Reform'u önermiştir. Zirai Reform'un amacı verimliği yükseltecek teknik yöntem ve uygulamaların yaygınlaştırılmasını sağlamaktı. Böylelikle hiç kimse bir mağduriyet yaşamayacakt1. ${ }^{87}$

Sağ fraksiyon; sol söylemi, ekonomik alanda kullanılan "Bu düzen değişmelidir." sloganını ile özdeşleştirmiştir. Sağ cenahın yorumuyla; 1973 seçim bildirgesi bütünüyle Batının Materyalist anlayışının bir yansımasıdır. Buna göre Marksizm'in bir basamak gibi görülmekte ' Özgürlüklerin hükümet eden iç ve dış sermaye kuvvetleri ile kısıtlandığı ve iktidar toplumun değil, yalnızca sermaye sahiplerinin iktidarıdır." iddiaları da, suiistimal edilmektedir. ${ }^{88}$ Sağ yaklaşıma göre, Ortanın Solu fikri, yalnızca CHP içindeki sola açılımın tezahürüdür. Hareketin devamının geleceği "Halkın istediği kadar sola açılma" sloganıyla kanıtlanmıştır. Bu doğrultuda CHP'nin varabileceği tek hedef Marksizm olacaktır. ${ }^{89}$ Ortanın Solu'na karşı parti dışında gelişen sağ muhalefette özellikle AP, kuramsal olarak geliştirdiği muhalefeti daha oportünist bir tutumla güçlendirmiş ve "Ortanın Solu Moskova'nın yolu!" sloganı ile hafızalara kazınan popülist bir karalama kampanyası yürütmüştür.

\section{Sonuç}

CHP'deki siyasal metamorfoz süreci aslında 1960'ların öncesine dayanmaktadır. Çok partili hayata geçişle beraber ' kurucu iktidar'" fonksiyonunu yitiren CHP, iktidarı yeniden eline alabilmek adına Demokrat Parti'nin sert ve demokrasiyle çelişen uygulamalarına karşı, demokrasiyi merkezine alan ve daha özgürlükçü söylemler geliştirmek mecburiyetindeydi. Nihayetinde 1957 erken seçimi için CHP'nin hazırlamış olduğu seçim programının yanı sıra 1959 yılında 14. Kurultay'da yayımlanan İlk Hedefler Beyannamesi ile değişim rüzgarları esmeye başlamış ve 1965 yılında Ortanın Solu açılımıyla da parti içerisinde uzun zamandır şekillenmeye çalışan siyasal metamorfoz süreci vücut bulmuştur. CHP de Ortanın Solu söylemi ile sınıfsal bir temeli barındıran devlet aygıtı karşısında ve parti geleneklerindeki "'halk için, halka rağmen" ilkesine karşıt olarak "halk için, halkla beraber" anlayışıyla "tavanın" değil 'tabanın" sesi olmayı hedeflemiştir. 'Halkla beraber' ş̧eklinde formülize edilen Ortanın Solu akımı, CHP'de parti dışı etkenlere bağlı olarak gelişse de, parti içerisinde hizipleşmelere, ayrılıklara neden olan çatışmalara rağmen bilhassa Bülent Ecevit, Turan Güneş, Deniz Baykal, İbrahim Öktem, Ahmet Yücekök, Haluk Ülman gibi isimler tarafindan parti politikası haline gelebilmesi için önemli mücadeleler verilerek savunulmuştur.

Ortanın Solu kavramı parti dışından daha ziyade parti içinde çok daha fazla tartışılmıştır. 1966 senato seçimlerinden sonra parti içinde ortaya çıkan ve "sağ kanat" olarak adlandırılan

\footnotetext{
85 Nihat İyriboz, "Devletçilik Kalkınmamızı Baltalıyor”, Ortam, Sayı 1, 1 Aralık 1964.

86 Aydın Yalçın, "AP ve İşçi Hareketi”, Ortam, Sayı 6, 1 Mayıs 1965.

87 “Toprak Reformu”, Ortam, Say1 4, 1 Mart 1965.

88 Celal Bozkurt, Kemalizm, Marksizm ve Ecevit, Boğaziçi Yayınları, İstanbul, 1976, s. 442.

89 Bozkur, s. 503.
} 
Turhan Feyzioğlu'nun liderliğindeki ' Sekizler Hareketi', Ortanın Solu'na karşı parti içi ilk etkili muhalefet grubu olmuştur. Sağ-Kemalizm olarak nitelendirilebilecek görüşe sahip olan "Sekizler Hareketi', Ortanın Solu akımını partinin sosyalist bir kimliğe büründürülmesi girişimi olarak yorumlamış ve CHP'nin 'Atatürk'ün partisi olma vasfindan uzaklaştığı'" gerekçesiyle partiden ayrılmıştır. 1969 Seçim Bildirgesi’nin ardından İnönü’nün Ortanın Solu üzerindeki etkisinin azalmasıyla Kemal Satır ve Nihat Erim gibi isimler de Ortanın Solu'na karşı muhalif bir tutum izlemeye başlamıştır. "Ortanın Göbekçileri” adı verilen ve Kemal Satır'ın liderliğini üstlendiği muhalefet grubu, kendilerini Ecevit ve grubundan daha tecrübeli görerek seçim bildirgesi ve MYK'nın uygulamalarını sert bir biçimde eleştirmiştir. Özellikle“Toprak işleyenin, su kullananın” ilkesinin yasadışı olduğunu ileri süren "Ortanın Göbekçileri”, Ecevit'in Atatürk Devrimleri hakkında yaptığı konuşmaları da şiddetli bir biçimde tenkit etmiştir. Daha sonra 'Sekizler Hareketi"' ile birleşen "Ortanın Göbekçileri”, Ortanın Solu'na karşı muhalefette merkez muhalefeti oluşturmuştur. Bülent Ecevit'in yükselişine kadar Ortanın Solu'nu destekleyen ancak Ecevit'in yıldızının parladığı zamanlarda aralarında anlaşmazlıklar yaşanan Üçüncü Dünyacılar da Ortanın Solu ve parti içi muhalefet arasında dengeyi sağlayan gruplardan biri olmuştur. Yöntem hususunda Ortanın Solu akımıyla zıt düşen bir başka grup ise Orhan Kabibay'ın önderliğini yaptığı, askeri ve bürokratik bir devrimden yana tavır takınan Sosyalist-Sol ekibidir. Tüm bunların dişında Ortanın Solu içinde bulunan alt gruplar arasındaki iktidar mücadelesi ve il örgütleri içerisindeki nüfuz mücadeleleri 1980 Darbesine değin sürerken parti merkezinde 22. Kurultay'da başlayan Baykalcılar ve Karadeniz Cuntası'nın savaşı baş göstermiştir.

Görüldüğü gibi Ortanın Solu anlayışı, CHP'de farklı değerlendirilip gruplaşmalara zemin hazırlamışken tartışılmaya başlandığ 1 dönemde, parti dışı diğer cephelerin de gündem konusu olmuştur. Ortanın Solu akımı ilk zamanlar, parti dışı sol gruplar tarafından olumlu karşılanmış hatta TİP, sağ cenaha karşı "Milli Kurtuluş Cephesi" çatısı altında CHP'ye bir ittifak kurmayı bile önermiş̧ir. Ancak bu öneri, Ecevit tarafından reddedilince TïP cephesinde CHP'ye karşı eleştiriler başlamıştır. 1969 yılında eski DP'lilere affın gündeme gelmesi ile birlikte sol cenahın sert eleştirileri giderek şiddetlenmiştir. Bu sürecin ardından Ortanın Solu'nu kendileri için bir engel olarak yorumlayan sol kesim, Ortanın Solu'nu halk dalkavukluğu olarak görmüş ve CHP'yi AP'leşme hatta DP'leşme özlemi içerisinde olmakla suçlamıştır. Sol cenaha göre CHP'nin Kemalist mayasını bozan bu yöneliş, devrimcileri küstürürken aynı zamanda asla CHP'ye AP tabanından oy olarak geri dönmeyecektir. Aynı zamanda Ortanın Solu'na karşı yönelen eleştirileri okları hareketin lideri Bülent Ecevit'e de yönelmiş Ecevit, sol muhalefetçe Mülkiye Cuntası'nın gölgesinde hareket etmekle suçlanmıştır. 1973 seçim bildirgesini çoğu yönden yetersiz bulan Sol muhalefete göre 1973 bildirgesi sol oyları toplamak adına yapılan siyasi bir hile olarak yorumlanmış ve CHP, KöyKent ve Toprak Reformu gibi konularla alakalı samimi olmamakla suçlanmıştır. CHP'nin NATO ve Ortak Pazar'a olan yaklaşımı da sol muhalefetin eleştirilerine konu olurken seçim bildirgesindeki ekonomik kilit noktalarını kamulaştırmaksızın, ulusal sanayiyi gümrük duvarlarıyla korumadan, milli endüstriyi uluslararası tekellerle rekabet edebilecek hale getirme düşüncesi yine sol kesime göre tam bir hayalcilik olarak değerlendirilmiştir.

Ortanın Solu'na karşı sağ fraksiyondaki muhalefet liderliğini ise sağ'ın en büyük partisi olan AP üstlenmiştir. Sağ muhalefetin yorumuna göre Ortanın Solu gizli bir sosyalizm 
programıdır ve CHP bu söylemle, Türkiye'nin dış düşmanlarının içerideki uzantılarına yataklık yapmaktadır. Komünizm karşıtlığı ile politikasını geliştiren sağ fraksiyon, başta TIP'e ardından da CHP'ye yüklenerek kendi ekonomik teziyle uyuşmayan devletçilik uygulamasını da şiddetle eleştirmiş, kalkınmanın önündeki en büyük engelin devletçilik olduğunu savunmuştur. Sağ fraksiyon, özellikle "Bu düzen değişmelidir." sloganını sol söylem ile özdeşleştirmiş, 1973 seçim bildirgesini tamamen Batı'nın materyalist anlayışının bir yansıması olarak değerlendirmiş ve Ortanın Solu fikrini, yalnızca CHP içindeki sola açılımın tezahürü olarak görmüştür. Sağ yaklaşıma göre, CHP'nin bu yöntem ile varabileceği tek nokta marksizm olacaktır. Ortanın Solu'na karşı sağ fraksiyondaki muhalefet liderliğini üstlenen AP, komünizm tehlikesini öne sürerek Ortanın Solu'na karşıt bir kamuoyu oluşturmaya çalışmıştır.

\section{Kaynakça}

Süreli Yayınlar

(1967, Ekim 18). Ulus.

(1970, Temmuz 6). Cumhuriyet.

(1970, Temmuz 10). Cumhuriyet.

Abadan, N. (1966, Temmuz 1). 1966 Kısmi Senato Seçimlerinin Tahlili. Forum.

Aksoy, M. (1966). '’Demokrasinin Akıbeti-CHP ve Ortanın Solu'. Forum.

Aksoy, M. (1977). Sosyalist Enternasyonal ve CHP. Ankara: Tekin Yayınevi.

Aslan, İ. (1965, Haziran 11). "Seçimler Arifesinde Siyasi Partilerin İdeolojik Görüntüleri', Yön.

Avcıoğlu, D. (1962, Eylül 12). 'Sosyalist Gerçeklik'. Yön.

Avcıoğlu, D. (1962, Ağustos 22). 'SSosyalizm Anlayışımız'. Yön.

Avcıoğlu, D. (1966, Ekim 14). 'Bir Sosyalist Stratjinin Esaslar1'. Yön.

Banguoğlu, T. (1965, Ekim). Atatürk Milliyetçiliği. Ortam.

CHP Yön Aranıyor. (1962, Nisan 4). Yön.

İyriboz, N. (1964, Aralık 1). 〈〉Devletçilik Kalkınmamızı Baltalıyor»». Ortam.

Kırıkoğlu, K. (1974, Aralık 9-15). ' Kavganın Nedeni'. Yank1.

Savc1, B. (1967, Mayıs 13). "8'"lerin Yeri ve Yolu'. Akis.

‘'Seçimler ve Yön’. (1965, Eylül 10). Yön.

‘'TİP’in İç Yüzü'’. (1965, Mayıs 1). Ortam.

Toker, M. (1960). Yurtta Olup Bitenler. Akis.

'Toprak Reformu'. (1965, Mart 1). Ortam.

Yalçın, A. (1965, Mayıs 1). 'AP ve İşçi Hareketi'”. Ortam.

Kitaplar 
Ayata, A. G. (1992). Cumhuriyet Halk Partisi (Örgüt ve İdeoloji). İstanbul: Gündoğan Yayınları. Yayınları.

Bila, H. (1987). Sosyal Demokrat Süreç İçinde CHP ve Sonrası. İstanbul: Milliyet

(2008). CHP 1919-2009. İstanbul: Doğan Kitap.

Bozkurt, C. (1967). Siyasi Tarihimizde CHP Dünü, Bugünü ve İdeolojisi. Ankara.

(1976). Kemalizm, Marksizm ve Ecevit. İstanbul: Boğaziçi Yayınları.

Crick, B. (2012). Demokrasi. Ankara: Dost Kitabevi.

Emre, Y. (2013). CHP, Sosyal Demokrasi ve Sol. İstanbul: İletişim Yayınları.

Feyzioğlu, T. (1986). Atatürk ve Milliyetçilik. Ankara: Atatürk Araştırma Merkezi Yayınları.

İnönü, İ. (1967). İnönü Ortanın Solunu Anlatıyor CHP Nedir? Ne değildir? Ankara: CHP Genel Sekreterliği Yayınları.

İsvan, A. (2002). Başkent Gölgesinde İstanbul. İstanbul: İletişim Yayınları.

Kardam, A. (1976). CHP Nedir? Ne Değildir? Ankara: Ülke Yayınları.

Neftçi, N. (1997). Demokrasinin Kilittaşı Anılar. Ankara: TESAV.

Satır, K. (1972). CHP'de Bunalım. Ankara: Nüve Matbaası.

Sencer, M. (1971). Türkiye'de Siyasal Partilerin Sosyal Temelleri. İstanbul: Geçiş Yayınları.

Simav, A. (2009). Turan Güneş’in Siyasi Kavgaları. İstanbul: Agora Kitaplığı.

Toker, M. (1991). DP Yokuş Aşağ1 - Demokrasimizin İsmet Paşa'lı Yılları 19441973. Ankara: Bilgi Yayınevi.

Dergi

Ecevit, B. (1995). Sol'a Yönelişin Öncülüğünü CHP'nin Üstlenmesini İstiyordum. Tarih ve Toplum, 61-64.

Fedayi, C. (2004). ' 'Ortanın Solu Akımı'”. Liberal Düşünce, 163-183.

Haluk Ülman, A. Y. (1972). 'CHP'deki Değişikliğin Gerçek Anlamı'. Özgür İnsan.

Tuğluoğlu, F. (2017). CHP'nin 14. Kurultayı ve İlk Hedefler Beyannamesi. Atatürk Yolu Dergisi.

Uzun, H. (2012). İktidarını Sürdürmek isteyen Bir Partinin Kimlik Arayış1:Cumhuriyet Halk Partisi'nin 1947 Olağan Kurultayı. Dokuz Eylül Üniversitesi Atatürk İlkeleri ve İnkılap Tarihi Enstitüsü , 101-139.

\section{Tez}

Esmer, Gülsüm T., (2006). Türk Siyasal Yaşamında Ortanın Solu Politikası, Dokuz Eylül Üniversitesi Sosyal Bilimler Enstitüsü Tarih Ana Bilim Dalı Yayınlanmamış Yüksek Lisans Tezi. 
Fedayi, C. (2003). Turan Güneş: Siyasal Yaşamı ve Siyasal Düşüncesi. Ankara: Hacettepe Üniversitesi Yayınlanmamış Doktora Tezi.

\section{Bildirge}

CHP 19. Kurultay Bildirgesi. (1968, Ekim 20). İsmet İnönüınün Açı1ış Konuşması. Ankara: Ulusal Basımevi.

\section{EK. 1}

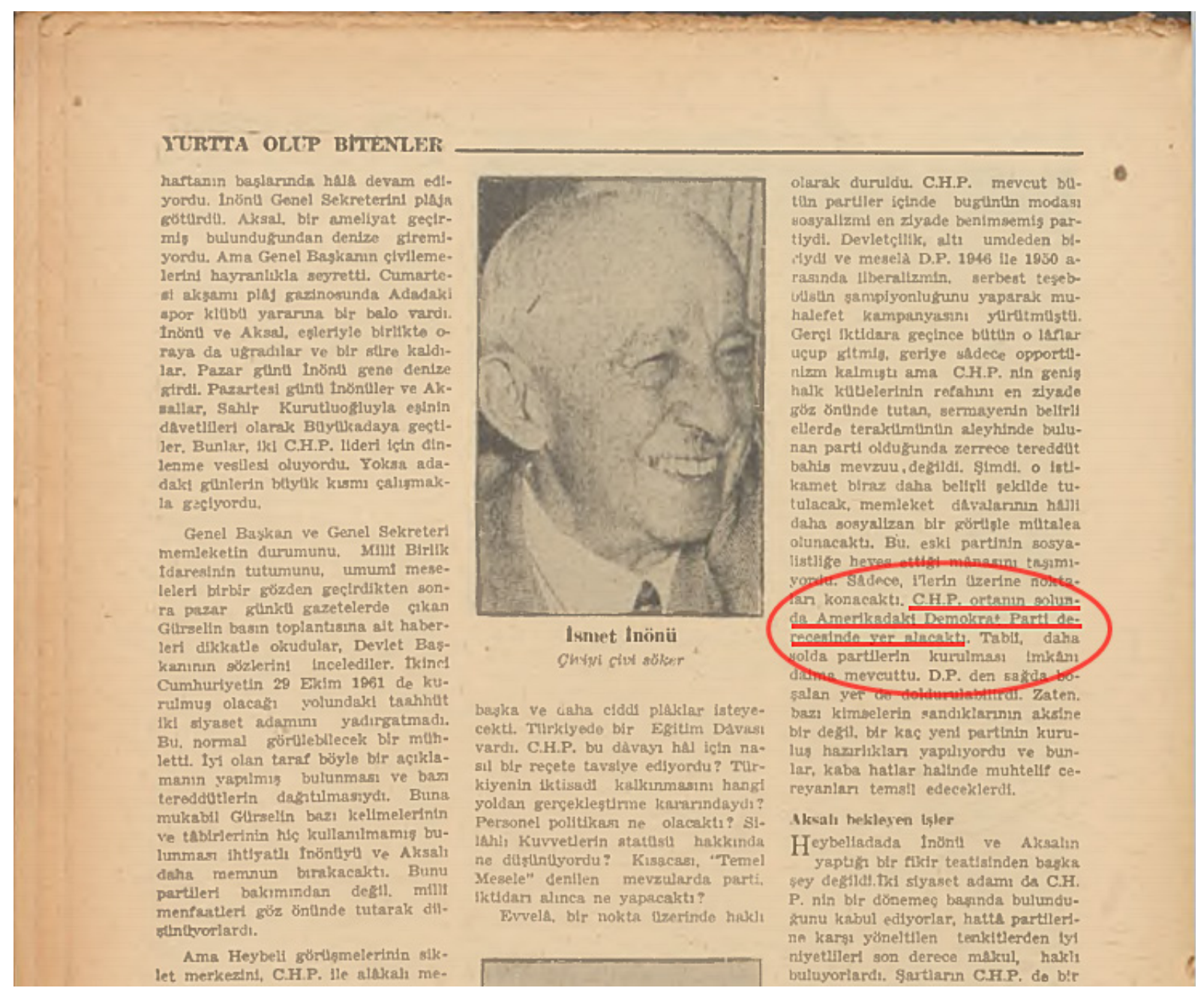

'Ortanın Solu' kavramı zannedildiği gibi Türk basınında ilk kez Milliyet gazetesinde İsmet İnönü’nün Abdi İpekçi ile yaptığı röportajda değil, henüz 1960 yılında, AKİS dergisinin 31 Ağustos 1960 tarihli 315. sayısında yer almıştır. (Metin Toker, "Yurtta Olup Bitenler”, Akis, 31 Ağustos, 1960, say1:315, s. 26.) 